\title{
Changing the Meaning of "Literacy" in Language Education Policy in South Korea
}

\author{
Bomi Jeong
}

\begin{abstract}
The purpose of this study is to diachronically consider the meaning of "literacy" in language education policy in South Korea. The concept of the modern enlightenment period was "modern literacy" and "Korean language literacy." During the Japanese occupation, the meaning of literacy was divided into two parts: "Japanese language literacy" and "Korean language literacy." From the modern enlightenment period to the founding of Korea, the concept of literacy had been managed as a tool of basic communication and a heritage of the national spirit from old times. This concept, however, was dismantled during when the national curriculum was established: a) for the promotion of literacy, the national spirit was at a low rate; and b) instead of basic and practical literacy, a critical and high-level literacy tended to be emphasized. For an accurate and productive functionality in explaining language phenomena, the changing meaning of literacy must be considered thoroughly.
\end{abstract}

Index Terms-Literacy, Korean language education policy, national spirit, basic knowledge, practical knowledge.

\section{INTRODUCTION}

"Literacy" is defined as "the ability to read and write in the native language" [1]. This concept can be enabled through a change of the holder from the elite domain to the public domain, and the development of writing from a laborious physical activity to a gentle mental expression. Such an expansion of this concept is active even today. An objective of literacy entails not only reading materials or writing exercises but also media that require watching or listening, such as by using computers or watching movies. In addition, an attribute of literacy is not only an understanding at the functional level, but a critical analysis at a high level.

This phenomenon can be observed not only in Western society but also in South Korea. In South Korea, the concept of literacy has been emphasized as the main purpose of Korean language education since the appearance of modern Korean language education, akin to in Western society, in which ways to promote national literacy are actively discussed as a social agenda. The objective of this study is to reveal the distinct characteristics of Korean language education, and to fulfill this purpose, we diachronically consider the meaning of literacy in language education policy in South Korea.

Manuscript received February 6, 2014; reviewed May 6, 2014.

Bomi Jeong is with the Department of Korean Language Education, Seoul National University, Seoul, 151-748 South Korea (e-mail: yukinong24@gmail.com).

\section{HISTORY OF THE CONCEPT OF "LITERACY" IN KOREAN LANGUAGE EDUCATION POLICY}

\section{A. Modern Enlightenment Period (1895 - 1910.8.)}

The modern concept of Korean language education began to be used seriously during the modern enlightenment period. This period is characterized by the change in objective of literacy from Chinese to Korean (in most cases mixed with Chinese), and the expansion of the subject of literacy from the nobility to the public. In a decree issued on November 21, 1894 , Korean was declared as the first language, with the use of Chinese allocated to a second language for translation: "Article 14. This decree declares that Korean language should be the model language, (on the other hand) Chinese could be attached to translate Korean or two languages could be used mixed" [2].

"Chinese language literacy" as "literacy in the Joseon Dynasty," in addition to "Korean language literacy" as "modern literacy" coexisted at that time. This issue can be classified into two positions: successive attitude in favor of the positive effect of the Chinese language, and severing attitude in favor of adopting Western culture, as shown in A and $\mathrm{B}$, respectively.

1) Students who are literate in the Chinese language have a lofty idea, good conduct, and an excellent understanding of each field of study. However, students who are not literate in Chinese do not [3] (see Fig. 1).

2) Children usually enter the Seo-dang (primary school in the Joseon Dynasty) at age 7 or 8, and have to master Cheon-ja-moon (the basic 1,000 Chinese characters) from scratch. Students repeat only the teacher's recitation, and after all, the letters are only read aloud with not comprehended [4] (see Fig. 2).

In 1), knowledge regarding the Chinese language is a sign of "a lofty idea, good conduct, and an excellent understanding," contrary to 2), which criticizes students' parroting. These texts show the meaning of literacy in the modern enlightenment period. At that time, people believed that "national language literacy" guaranteed an easy understanding. The spirit of the times was "enlightenment," of which the core purpose was to enlarge the range of rights to knowledge. The point was on whether one understands the reading material on their own, rather than on whether people understand the reading material, as shown in the following education-related legislation: "2. Despite the Chinese language being the main language mediating instruction in Seo-dang, the practical needs of the Korean language should also be considered. If there are no other obstacles, the Korean language could be instructed beside the Chinese language" [5]. This article shows that Korean literacy can be used in 
actual life as well as in the classroom. Such a demand on practical literacy appeared in this time, and had an critical effect thereafter.

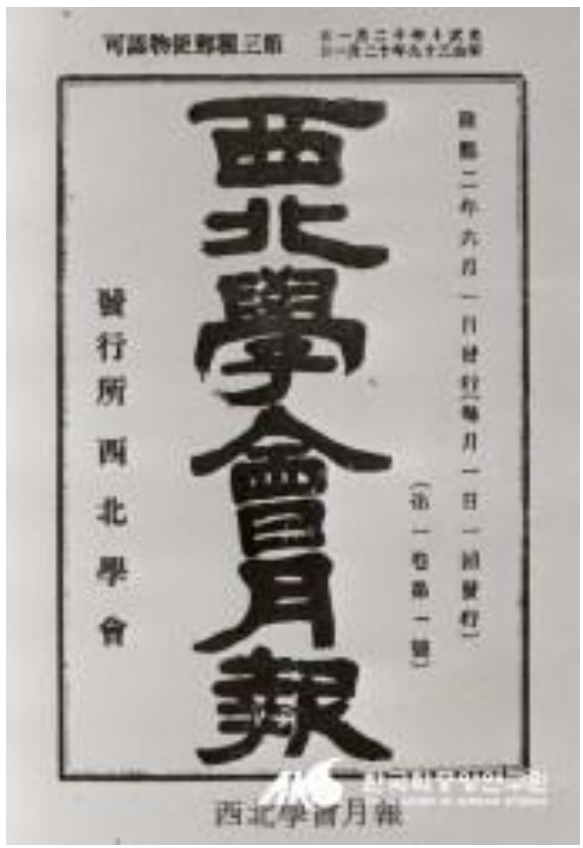

Fig. 1. First issue of A Monthly Educational Report in Regions of the Northwest.

\section{B. Period of Japanese Occupation (1910.9 - 1945.8.)}

Literacy during the Japanese occupation also reflected the demand for easy understanding and practical use. Further, the concept of "national language literacy" (originally Korean language literacy in the modern enlightenment period) is divided into two parts: Korean language literacy and Japanese language literacy. This was because the concept of "nation" entailed unrest because of the colonial administration. The aspects of division were shown in two ways: one emphasized an understanding of modern civilization rather than of literacy, with the meaning of understanding the separation of reading or writing, whereas the other allowed Japanese literacy to replace Korean literacy by using colonial rule as a rationale for integration.

1) The best concentrated subjects are practical ones such as mathematics, linguistics, and accounting. Mathematics is the subject that most students study hardest for. These sorts of subjects could be helpful in overcoming our wisdom and skills, which seem small and weak [6].

2) In the classroom of the first grade, when a teacher says “此は私の-” (“This is my-”), all the students say “고레와 와다꾸시노-" ("the same") in unison [7].

1) describes a position suggesting that students study hard for the practical subjects, whereas 2) provides an example of an instruction in Japanese literacy. As the language education policies that require Japanese literacy take effect, such aspects are maximized. On April 1938, the policy that allowed teachers and students to use Korean only in a few subjects took effect; On May 1942, the Japanese exclusive policy was implemented, which involved military systems, a volunteer soldier system, and conscription. As Korean became integrated into Japanese, certain writers used to agonize over how to sustain the Korean spirit of resistance.
They would use Japanese to describe those days vividly, and to sneer at the Japanese Empire.

\section{Period of Founding the Country (1945.9. - 1955.7.)}

The period of the nation's founding includes the American military government period, the government establishment period, wartime period, and post-war period. For language education policy, this entails the period until the enactment of the first national curriculum. At that time, there was a call to replace Japanese literacy, which had represented basic and practical literacy since Japanese colonial rule, with Korean literacy. This process was complex and difficult, because the main language used in the official gazette was English during the American military government period, and it was translated not only into Korean but also to Japanese when published.

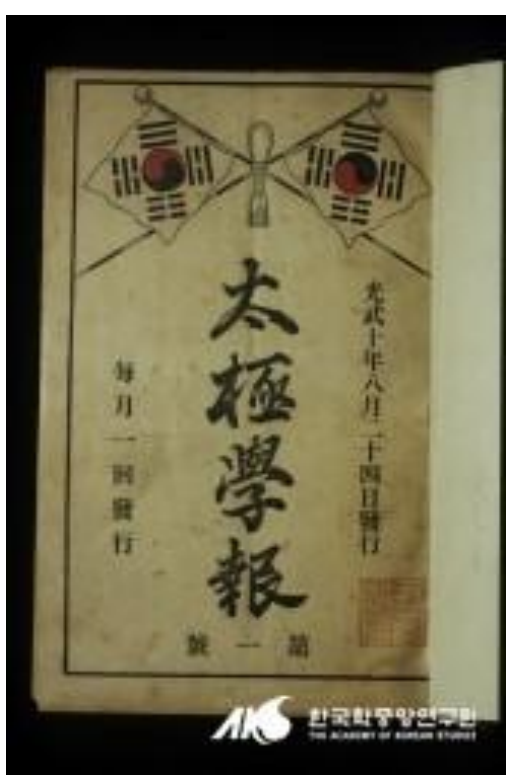

Fig. 2. First issue of A School Newspaper of Taegeuk.

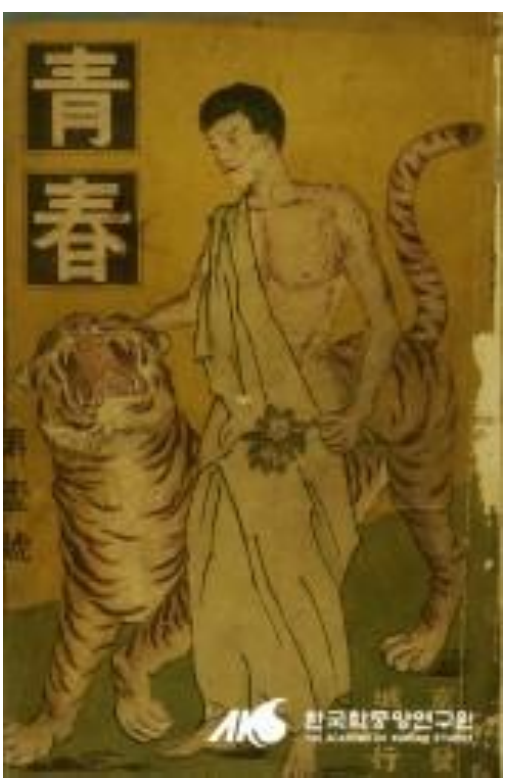

Fig. 3. First issue of Cheong-choon (Youth).

Despite these difficulties, considerable effort was exerted to emphasize Korean literacy through the refinement movement of the national language. The Ministry of Education of the American military government established a Refinement of Korean Committee (1947.1.) to replace 
Japanese vocabulary words with Korean. In addition, the rules of Korean orthography legislated in 1933 were formulated by the American military government. To update the legislation of that time was also a part of the government's move.

What befell that movement was the argument that Korean literacy represents national ethics. An outline program of instruction during the American military government period indicated that reading could be used as a tool to improve the consciousness of the state and property as a nation: "1. Reading Korean: to raise students' consciousness of the nation state through accustoming, solving, appreciating, criticizing, and dictating, to clarify morality and intelligence, to enjoy practice, labor, and literature, to get to be sound in mind and body, and to grow property as a nation" [8] (see Table I and Table II).

TABLE I: THE LESSON TIME NUMBER OF EACH GRADE PER YEAR (IN PRIMARY SCHOOL)

\begin{tabular}{ccccccc}
\hline & G1 & G2 & G3 & G4 & G5 & G6 \\
\hline Reading & 240 & 240 & 240 & 240 & 200 & 180 \\
\hline $\begin{array}{c}\text { Listening } \\
\text { and } \\
\text { speaking }\end{array}$ & 40 & 40 & 40 & 40 & 40 & 36 \\
\hline Composing & 40 & 40 & 40 & 40 & 40 & 36 \\
\hline Writing & 40 & 40 & 40 & 40 & 40 & 36 \\
\hline
\end{tabular}

TABLE II: THE LESSON TIME NUMBER OF EACH GRADE PER YEAR (IN SECONDARY SCHOOL)

\begin{tabular}{ccccccc}
\hline & \multicolumn{3}{c}{ Beginning Level } & \multicolumn{3}{c}{ Advanced Level } \\
\cline { 2 - 7 } & G1 & G2 & G3 & G1 & G2 & G3 \\
\hline Reading & 148 & 148 & 111 & 74 & 74 & 74 \\
\hline $\begin{array}{c}\text { Composing } \\
\text { and } \\
\text { Grammar }\end{array}$ & 37 & 37 & 74 & 37 & 37 & - \\
\hline $\begin{array}{c}\text { History of } \\
\text { Korean } \\
\text { Literature }\end{array}$ & - & - & - & - & - & 37 \\
\hline
\end{tabular}

Literacy during the nation's founding became a feature of change in cognizance regarding the Chinese language. In the modern enlightenment period and during the Japanese occupation, using Korean included mixing Chinese, whereas the argument that pure Korean should be used arose and generated controversy during the founding of Korea. It shows that the Chinese status had declined, and people questioned why Chinese, a foreign language, should be used during the establishment of the national curriculum.

\section{Period of Using the National Curriculum (1955.8. -)}

Language education policy from Korea's founding had progressed concretely and systematically until the establishment of the national curriculum in 1955. The national curriculum has been revised 10 times to date, and herein we can find a new viewpoint for the definition of literacy. The emphasis of Korean language literacy is no longer the focal point, and the concept of the national spirit has been relegated to old reasoning. The present interest of Korean language education is critical and multicultural literacy in the era of globalization. Therefore, the concept of literacy in Korea entails coming to embrace various objects and properties.

Literacy was defined as that which has a connection with the life and emotions of the nation until the seventh curriculum, and the revised curriculum in 2007 stated similarly that the character of the curriculum regarding the Korean language is "to build up future-oriented and healthy national spirit," and its purpose is "to understand the essence of Korean language activities and Korean literature generally, to use Korean precisely and effectively considering contexts, to comprehend Korean culture justly, and to grow the ability and attitude to develop Korean language and create new Korean culture" [9]. However, the 2009 revised curriculum underwent a change; it no longer used the term "national spirit" in the main text, and regarded the concept of a nation as neutral, such as is sex, disability, region, and race [10].

This can be interpreted as a result of the current social atmosphere emphasizing internationalization and diversification. Mostly, the language policies or language education policies emphasize social integration. As of recently, people believe that integration can be achieved by maintaining neutrality and admitting diversity [11], whereas in the past an appeal for the national spirit guaranteed a voluntary bond [12]. Because the Korean language has been regarded as a pure and neutral language, rather than an ideological language filled with national zeal, the concept of literacy has to break shutdown. Therefore, the concept of literacy used in the educational context has considerable affinity with "knowledge" or "academic ability."

\section{CONCLUSION}

To date, studies on the concept of literacy have aimed to plot the contents and methods of Korean language education. A common point of these studies is their regarding literacy as a competence depending on the contemporary context [13]-[16]. Consequently, the concept of literacy has been used to refer to almost all ideal abilities as a goal of Korean language education. Accordingly, we can find the concept of literacy fluid and widely through the mentioned history.

It is of greatest advantage to use the concept of literacy not only for the basic functions of reading and writing but also for critically considering the contexts or reflexive discourse. In addition, that a keyword exists to embrace all the aims is of importance. When the current concept of literacy, however, is expected to cope too much with the assignments of Korean language education, the original intention of literacy becomes concealed. Therefore, literacy can currently naturally be substituted with "knowledge" or "problem-solving ability."

Because literacy is concerned with the literary language in the original language, and the domain of literary language has not disappeared despite the overwhelming amount of digital media, the popularity of the concept of literacy should be limited. Other terms are available to refer to these high-level abilities in order to understand texts thoughtfully, such as "the ability of critical thinking." The concept of literacy is more useful for the level of basic education, and it is more practical when defined as a communication tool.

\section{REFERENCES}

[1] R. Venezky, "Literacy," in T. L. Harris and R. E. Hodges(eds.), The Literacy Dictionary: The Vocabulary of Reading and Writing, IRA, 1995. 
[2] King Gojong, "The Initial Decree," in Y. Yoon and K. Kim(eds.), A History of Korean Language Education from 1901 to 2000, Seoul: Seoul National University Press, 2006, vol. I.

[3] D. Kim, "An Inadequacy about the educational world in regions of the northwest," A Monthly Educational Report in Regions of the Northwest, vol. 14, July 1909.

[4] E. Jang, "Report about evils of each school's present condition," A School Newspaper of Taegeuk, vol.25, Aug. 1908.

[5] An Instruction of the Education Ministry, The Education Ministry, 1908.

[6] C. Choi "An essay for a visiting to the schools: Whimoon high school," Cheong-choon (Youth), vol. 4, Jan. 1915.

[7] C. Choi, "An essay for a visiting to the schools: Boseong high school," Cheong-choon (Youth), vol. 3, Dec. 1914.

[8] An outline program of instruction of American military government period, United States Army Military Government in Korea, Sep. 1947.

[9] The 2007 revised National curriculum, Korea: Ministry of Education, 2007.

[10] The 2009 revised National curriculum, Korea: Ministry of Education, 2012.

[11] S. May and N. H. Hornberger, "Language Education, Pluralism and Citizenship," Language Policy and Political Issues in Education, New York: Springer, 2008.

[12] K. Kojin, Nation and Aesthetics, Tokyo: Iwanami Shoten, 2004.
[13] M. Kim, "The Changed Aspects of the Concept of Literacy and the Directions of Reconceptualization," Korean Language Education, vol. 110, pp. 15-43, Feb. 2003

[14] H. Jo, "The New Planning for the Education of Classical Literacy," Korean Language Education Research, vol. 21, pp. 121-155, Dec. 2004.

[15] H. Jeong, "Changes of Literacy and Model of Korean Language Curriculum in a Semiotics Perspective," The Journal of Curriculum Studies, vol. 26, no. 4, pp. 149-172, Dec. 2008.

[16] S. Shim, "Issues for Literacy Education in Multi-Cultural Society," Korean Language Education Research, vol. 35, pp. 331-359, Aug. 2009.

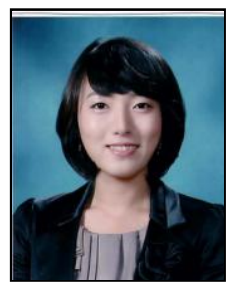

Bomi Jeong was born in Busan, South Korea on Oct. 24 1987. Ms. Jeong was admitted to the Department of Korean Language Education, Seoul National University in 2006, and graduated in 2010. After that, she studied for a master's degree on Korean classical literature education, and received her degree in 2012 The thesis of her master's degree is "A Study on Teaching the World Figure and World Recognition of $<$ Ku-un-mong >." Ms. Jeong has been in a Ph.D. program since 2013, and she is currently working at the Korean Language Education Research Institute, Seoul National University. 